\title{
PANDUAN PRAKTIKUM FISIKA DASAR 1 BERBASIS GUIDED INQUIRY TERHADAP PENINGKATAN HARD SKILLS DAN SOFT SKILLS MAHASISWA
}

\author{
Suprianto*, S.Ida Kholida, Herman Jufri Andi \\ Program Studi Pendidikan Fisika, Universitas Islam Madura, Indonesia
}

\begin{abstract}
This study aims to analyze the significant influence of the use offirst basic physics guide based on a guided inquiry to increased hard skills and soft skills of students. The experimental design used was "One Group Pretest-Postest Control Groups Design". This research was conducted at Integrated Laboratory of Islamic University of Madura. The sample of the study is the students who follow the first Basic Physics Practicum. The instruments used are hard skills observation sheet and student soft skills. Data analysis using SPSS16 for windows software help. Based on the research results, the average value of hard skills posttest is 4.01 with the category "Good", while the average value of soft skills is 4.35 which is categorized as "Excellent". For analysis using SPSS16 for windows obtained t-test hard skills and soft skills of student equal to 13,175 and 12,551 with sig. 0.00. This indicates that there are significant differences in students' hard skills and soft skills during pretest and posttest. From the result of the research, it can be concluded that there is a significant influence of the use offirst basic physics guide based on a guided inquiry to increased of hard skills and soft skill of students.
\end{abstract}

Keywords: guided inquiry; hard skills; soft skills

\begin{abstract}
Abstrak
Penelitian ini bertujuan untuk menganalis is adanya pengaruh yang signifikan penggunaan panduan praktikum fisika dasar 1 berbasis guided inquiry terhadap peningkatan hard skills dan soft skill mahasiswa. Rancangan eksperimen yang digunakan adalah " One Group Pretest-Postest Control Groups Design". Penelitian ini dilakukan di Laboratorium Terpadu Universitas Islam Madura. Sampel penelitian adalah mahasiswa yang mengikuti matakuliah Praktikum Fisika Dasar 1. Instrumen yang digunakan adalah lembar pengamatan hard skills dan soft skills mahasiswa saat praktikum fisika dasar 1. Analisis data menggunakan bantuan software SPSS16 for windows. Berdasarkan hasil penelitian diperoleh nilai rerata posttest hard skills sebesar 4,01 dengan kategori "Baik", sedangkan nilai rerata soft skills sebesar 4,35 yang berkategori "Sangat Baik". Untuk uji analisis menggunakan SPSS16 for windows diperoleh $\mathrm{t}$ hitung hard skills dan soft skills mahasiswa sebesar 13,175 dan 12,551 dengan sig. 0.00. Hal ini menunjukkan bahwa ada perbedaan yang signifikan hard skills dan soft skills mahas is wa saat pretest dan posttest. Dari hasil penelitian dapat disimpulkan bahwa ada pengaruh yang signifikan penggunaan panduan praktikum fisika dasar 1 berbasis guided inquiry terhadap peningkatan hard skills dan soft skill mahasiswa.
\end{abstract}

Kata kunci: guided inquiry; hard skills; soft skills

DOI : http://dx.doi.org/10.21067/mpej.v1 i2.2073

Diterima: Agustus 2017; Disetujui: September 2017

Universitas Islam Madura

merupakan salah satu perguruan

* Corresponding Author:

suprianto@fkip.uim.ac.id tinggi swasta terkemuka di Pulau Madura. Program studi pendidikan fisika merupakah salah satu program 
studi yang ada di Universitas Islam Madura dan satu-satunya program studi yang ada di Pulau Madura. Pada Program Studi Pendidikan Fisika FKIP UIM, matakuliah Fisika Dasar merupakan matakuliah wajib yang harus ditempuh oleh mahasiswa. Fisika dasar sebagai matakuliah teori selalu diikuti oleh matakuliah Praktikum Fisika Dasar sebagai satu kesatuan yang utuh.

Matakuliah praktikum fisika dasar dalam pelaksanaannya dilakukan secara terpisah dari perkuliahan teori, memiliki bobot 1 sks. Matakuliah ini dimaksudkan untuk memberikan landasan fisika yang bertolak dari pengetahuan fisika yang telah diperoleh dari mata kuliah teori fisika dasar 1. Topiktopik yang dipraktikumkan mencakup massa jenis zat padat bentuk kontinyu, koefisien gesekan, Ayunan Sederhana, Tetapan Pegas, Momen Inersia, Harga Air Kalorimeter, Panas Jenis Zat Padat dan Peneraan termometer. Capaian pembelajaran (Learning Outcome) matakuliah praktikum fisika dasar 1 adalah dapat menguasai konsep dasar fisika dan menganalisis permasalahan terkait dengan fenomena fisika secara logis, kritis, inovatif serta mengembangkan kemampuan berfikir dan sikap ilmiah yang berhubungan materi praktikum pengukuran, Dinamika Partikel dan Rotasi, Osilasi harmonik sederhana (Bandul dan pegas), Suhu dan kalor dengan penuh tanggung jawab sesuai dengan prinsip, teori, hukum, dan kaidah yang berlaku dalam fisika. Matakuliah praktikum fisika dasar dimaksudkan agar mahasiswa memiliki ketrampilan laboratorium dalam bidang fisika dasar.

Kegiatan

praktikum mempunyai 5 tujuan, yaitu: (1) untuk meningkatkan pengetahuan ilmiah; (2) untuk mengajarkan keterampilan eksperimen; untuk mengembangkan 'sikap ilmiah' seperti berpikiran terbuka, bersikap objektif, dan kesediaan untuk menangguhkan penilaian; (4) dapat mengembangkan keahlian, dan dapat memberikan penilaian dan (5) untuk memotivasi peserta didik, dengan simulasi yang menarik dan menyenangkan (Hodson dalam Abraham, 2011). Dengan adanya praktikum mahasiswa akan termotivasi untuk meningkatkan 
hard skills dan soft skill yang mereka miliki.

Hard skills dan soft skills sangat dibutuhkan saat memasuki dunia kerja. Keberhasilan seseorang $80 \%$ ditentukan oleh kecerdasan emosional (EI) dalam wujud soft skills berupa sikap/karakter dan $20 \%$ ditentukan oleh kecerdasan intelektual (IQ) yang merupakan bagian dari hard skills (Goleman dalam Forum Mangunwijaya VII, sebagaimana dikutip oleh Fitra dkk, 2016). Lulusan yang high competence dalam dunia kerja adalah mereka yang memiliki kemampuan dalam aspek teknis dan perilaku yang baik (Sudiana dalam Fitra dkk, 2016).

Hal yang sama juga dikemukakan Sailah (2008), yang menjelaskan bahwa faktor yang membawa dan mempertahankan kesuksesan seseorang adalah 80\% ditentukan oleh soft skills dan $20 \%$ ditentukan oleh hard skills. Pentingnya hard skills dan soft skills juga diungkapkan secara eksplisit dalam tujuan pendidikan nasional sebagaimana yang tercantum dalam UU Nomor 20 Tahun 2003 Tentang Sistim Pendidikan Nasional, Bab I,
Pasal 1 Ayat 1: Pendidikan adalah usaha sadar dan terencana untuk mewujudkan suasana belajar dan proses pembelajaran agar peserta didik secara aktif mengembangkan potensi dirinya untuk memiliki kekuatan spiritual keagamaan (soft skill), pengendalian diri (soft skill), kepribadian (soft skill), kecerdasan (hard skill), akhlak mulia (soft skill), serta ketrampilan yang diperlukan dirinya, masyarakat, bangsa, dan Negara.

Permasalahan hard skills dan soft skills mahasiswa yang masih minim juga terjadi pada matakuliah praktikum fisika dasar prodi pendidikan fisika FKIP Universitas Islam Madura. Beberapa faktor yang menyebabkan minimnya hard skills dan soft skills mahasiswa adalah 1) input mahasiswa yang berasal dari jurusan IPS atau kejuruan sehingga pengetahuan awal mahasiswa tentang fisika sangat rendah; 2) Kegiatan praktikum lebih menekankan pada hasil (produk) dan bukan pada proses, sehingga sedikit sekali kesempatan yang diberikan kepada mahasiswa untuk mengalami sendiri usaha dalam mengembangkan hard skills dan soft skills; 3) Berdasarkan 
hasil telaah pada modul panduan praktikum fisika dasar 1 yang digunakan, tidak mendorong mahasiswa untuk melatih hard skills dan soft skills. Hal ini disebabkan karena modul panduan praktikum fisika dasar 1 masih bersifat konvensional dengan petunjuk model resep (cookbook) sehingga mahasiswa kurang kreativitas dan aktivitas dalam kegiatan praktikum.

Padahal sebagai calon guru yang nantinya akan mengajar fisika kepada siswa-siswa di pendidikan menengah, mahasiswa perlu mengalami dan mengembangkan kemampuan kerja ilmiah (Aji \& Hudha, 2015) sehingga nantinya dapat membimbing siswanya untuk melakukan percobaan mandiri dalam belajar sains di Sekolah. Mahasiswa seharusnya juga mendapatkan pengetahuan, yang akan mempermudah untuk menguji, memodifikasi, mengubah ide awal yang telah dimiliki dan mengadopsi ide yang baru serta dapat mendorong berkembangnya hard skill dan soft skill.

Untuk mencapai Learning Outcome matakuliah praktikum fisika dasar 1 dan tujuan pendidikan nasional dibutuhkan pengembangan modul praktikum yang dapat melibatkan mahasiswa secara aktif dan meningkatkan hard skills dan soft skills mahasiswa. Modul panduan praktikum adalah pedoman pelaksanaan praktikum yang berisi tata cara persiapan, pelaksanaan, analisis data dan pelaporan yang disusun oleh seorang atau kelompok staf pengajar yang menangani praktikum tersebut dan mengikuti kaidah tulisan ilmiah..

Salah satu upaya untuk meningkatkan hard skills dan soft skills mahasiswa adalah dengan mengembangkan modul panduan praktikum fisika dasar 1 berbasis guided inquiry. Guided inquiry dapat melatih peserta didik membangun jawaban dan berpikir cerdas dalam menemukan berbagai alternatif solusi atas permasalahan yang diajukan oleh pendidik, mengembangkan keterampilan pemahaman konsep, membangun rasa tanggung jawab dan melatih proses penyampaian konsep yang ditemukan (Bilgin, 2009). Hal yang sama dikemukakan oleh Massialas dalam (Matthew dkk, 2013) yang mendefinisikan model inkuiri terbimbing adalah model 
mengajar yang memungkinkan siswa untuk bergerak selangkah demi selangkah dari mengidentifikasi masalah, mendefinisikan hipotesis, merumuskan masalah, mengumpulkan data, memverifikasi hasil, dan generalisasi kesimpulan. Keterampilan ilmiah dalam praktikum fisika dasar adalah kemampuan melakukan prosedur ilmiah dan kepemilikan sikap ilmiah. Dalam praktikum fisika dasar memerlukan keterampilan pengetahuan dan keterampilan psikomotorik (hard skills) yang memadai dan dilakukan melalui proses yang menuntut sikap ilmiah (soft skills) dari mahasiswa seperti jujur, bekerja sama, dan terbuka.

Berdasarkan hasil penelitian (Waliyah dkk, 2016) menyimpulkan bahwa ada perbedaan yang signifikan kemampuan kerja ilmiah mahasiswa sebelum dan sesudah menggunakan petunjuk kimia dasar 1 berbasis inkuiri terbimbing. Berdasarkan hasil penelitian (Ariesta dkk, 2011) menunjukkan perolehan persentase kerja ilmiah mahasiswa secara klasikal sebesar 91,67\% dengan kriteria sangat baik, sikap ilmiah dengan persentase $87,50 \%$ dengan kriteria sangat baik, penyusunan laporan oleh mahasiswa dengan persentase $76,88 \%$ dengan kriteria baik, serta peningkatan ratarata hasil belajar \{rata-rata gain pertemuan pertama 0,58 (sedang), pertemuan kedua 0,56 (sedang), pertemuan ketiga 0,7 (sedang), dan pertemuan keempat 0,93 (tinggi)\}. Hasil penelitian dari (Feriyadi dkk, 2015) menyimpulkan penggunaan LKS berbasis Inkuiri Terbimbing dapat meningkatkan KPS siswa pada materi pokok pencemaran dan dampaknya bagi makhluk hidup.

Berdasarkan uraian di atas maka diperlukan penelitian untuk menganalisis adanya pengaruh yang signifikan penggunaan panduan praktikum fisika dasar 1 berbasis guided inquiry terhadap peningkatan hard skills dan soft skill mahasiswa.

Manfaat penelitian ini adalah (1) Menghasilkan modul panduan praktikum yang dapat digunakan sebagai penunjang pada mata kuliah praktikum fisika dasar 1; (2) Meningkatkan Hard skills dan soft Skills Mahasiswa Calon Guru Fisika pada mata kuliah praktikum Fisika Dasar 1; (3) Membentuk "Self Concept" mahasiswa, 


\begin{abstract}
mengembangkan bakat atau kecakapan individu, memberi kebebasan mahasiswa untuk belajar sendiri.

$\begin{array}{rrr}\text { Hard } & \text { skill merupakan } \\ \text { penguasaan ilmu pengetahuan, }\end{array}$ teknologi dan keterampilan teknis yang berhubungan dengan bidang ilmunya. Hard skill lebih beriorentasi mengembangkan intelligence quotient (IQ). Dari kedua pendapat tersebut dapat disimpulkan bahwa hard skill merupakan kemampuan untuk menguasai ilmu pengetahuan, teknologi dan keterampilan teknis dalam mengembangkan intelligence quotient yang berhubungan dengan bidang ilmunya.
\end{abstract}

Tabel 1. Atribut hard skills dan soft skill mahasiswa dalam praktikum fisika dasar 1 berbasis guided inquiry

\begin{tabular}{ll}
\hline Kemampuan & Sasaran Kemampuan \\
\hline & Menggali informasi \\
& (Retrieving) \\
& Mengklasifikasi \\
& (Classifying) \\
Hard skills & merumuskan masalah \\
& (Making question) \\
& Mengidentifikasi dan \\
& mengontrol variabel
\end{tabular}

\begin{tabular}{ll}
\hline Kemampuan & Sasaran Kemampuan \\
\hline & (Identifying and \\
& controling variables) \\
& Membuat hipotesis \\
& (Making hypotheses) \\
& Mengukur (Meausuring) \\
& Menginferensi (Infering) \\
& Menganalisis (Analyzing) \\
& Mensintesis \\
& (Synthesizing) \\
& Mengekspresikan \\
& Gagasan (Expressing \\
& Ideas) \\
& Jujur(Honesty) \\
& Cermat (Carefully) \\
& Kerjasama \\
& (Collaboration) \\
& Disiplin (Dicipline) \\
& Rasa ingin tahu \\
& (Curiosity) \\
& Ulet/gigih (Persistence) \\
& Mengambil keputusan \\
& (Decision making) \\
& Tangung jawab \\
& (Responsibility) \\
&
\end{tabular}

$\begin{array}{rrr}\text { Ketrampilan } & \text { yang } & \text { termasuk } \\ \text { dalam hard } & \text { skills, } & \text { misalnya }\end{array}$


ketrampilan menggunakan alat dengan baik, menggali informasi, mengklasifikasi, keterampilan mengukur dan menganalisis data, ketrampilan menyusun laporan, dan merumuskan hipotesis. Dalam kegiatan pembelajaran hard skills merupakan hasil belajar yang tergolong pada ranah kognitif dan psikomotorik yang diperoleh dari proses pemahaman, hapalan dan pendalaman materi dari model-model pembelajaran yang dilakukan di kelas. Kemampuan hard skills mahasiswa dapat dinilai dari indeks prestasi yang diperoleh di setiap semester.

Berbeda dengan hard skills, soft skill yaitu kemampuan seseorang dalam berhubungan dengan orang lain (interpersonal skills) dan kemampuan seseorang dalam mengatur dirinya sendiri (intrapersonal skills) serta kemampuan tambahan seseorang dalam kepercayaan/kepedulian baik terhadap penciptanya maupun orang lain (ekstrapersonal skills). Soft skills lebih merupakan perilaku personal dan interpesonal yang mengembangkan dan memaksimalkan kinerja manusia, seperti coaching, kerjasama, inisiatif, dan pengambilan keputusan (Berthal dalam Sailah, 2008). Atribut soft skills meliputi nilai yang dianut, motivasi, perilaku, kebiasaan, karakter, dan sikap. Atribut soft skills ini dimiliki oleh seseorang dengan kadar yang berbeda, dipengaruhi oleh kebiasaan berpikir, berkata, bertindak, dan bersikap. Menurut Sailah (2008) ada 23 atribut soft skills yang yang dominan di lapangan kerja. $\mathrm{Ke} 23$ atribut tersebut diurutkan berdasarkan prioritas kepentingannya di dunia kerja, yaitu: inisiatif, etika/integritas, berpikir kritis, kemauan belajar, komitmen, motivasi, bersemangat, dapat diandalkan, komunikasi lisan, kreatif, kemampuan analitis, dapat mengatasi stres, manajemen diri, menyelesaikan persoalan, dapat meringkas, kerjasama, fleksibel, kerja dalam tim, mandiri, mendengarkan, tangguh, berargumentasi logis, dan manajemen waktu.

Sasaran kemampuan mahasiswa yang meliputi hard skills dan soft skills dalam praktikum fisika dasar berbasis guided inquiry dapat dilihat pada Tabel 1. 


\section{METODE PENELITIAN}

Penelitian ini dilakukan dengan dua tahap, yaitu tahap pertama merupakan pengembangan panduan praktikum fisika dasar 1 berbasis guided inquiry yang divalidasi oleh para ahli dibidangnya masingmasing.

Pada tahap kedua melakukan ujicoba skala besar dengan menggunakan penelitian eksperimen. Desain eksperimen yang digunakan adalah "One Group Pretest-Postest Control Groups Design" (Schreiber, 2011). Penelitian ini dilaksanakan di Laboratorium terpadu Universitas Islam Madura. Populasi dalam penelitian ini semua mahasiswa prodi pendidikan fisika Universitas Islam Madura sedangkan sampel penelitian adalah mahasiswa angkatan 2017-2018 yang menempuh matakuliah praktikum fisika dasar 1. Instrumen yang digunakan dalam penelitian ini adalah lembar validasi ahli tentang modul panduan praktikum fisika dasar 1 berbasis guided inquiry, lembar penilaian hard skills dan soft skill mahasiswa.

Analisis hasil penilaian hard skills dan soft skills mahasiswa pada praktikum fisika dasar 1 menggunakan uji normalitas dan uji hipotesis. Uji normalitas digunakan untuk melakukan pengujian terhadap normal tidaknya sebaran data yang dianalisis. Data yang normal dianggap mewakili populasi. Data yang diuji adalah data yang diperoleh dari hasil penilaian/observasi pada mahasiswa saat melakukan praktikum fisika dasar 1. Dalam penelitian ini, untuk melakukan uji nomalitas menggunakan One sample Kolmogorov Smirnov Test berbantuan software SPSS16 for windows. Sedangkan uji hipotesis yang digunakan dalam penelitian ini adalah paired-samples $t$ test berbantuan software SPSS 16 for windows.

Untuk format penilaian hard skills dan soft skills menggunakan lembar penilaian yang nampak pada Gambar 1.

Hasil penilaian hard skills dan soft skills inilah kemudian dihitung dengan menggunakan rumus sebagai berikut:

penilaian $=\frac{\text { Banyaknyaskor yang diparolah }}{\text { banyalnya }}$ 


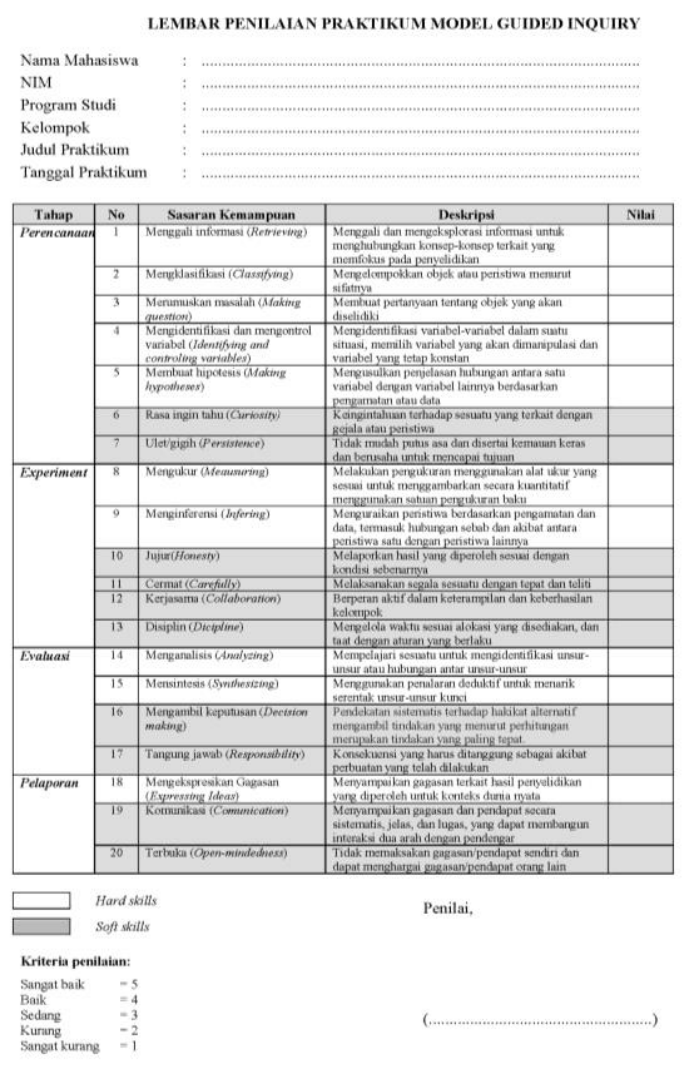

Gambar 1. Lembar penilaian hard skills dan soft skills mahasiswa

Kriteria penilaian hard skills dan soft skills mahasiswa saat praktikum fisika dasar 1 nampak pada Tabel 2.

Tabel 2. Kriteria penilaian hard skills dan soft skills

\begin{tabular}{ll}
\multicolumn{1}{c}{$\begin{array}{c}\text { Interval } \\
\text { Nilai }\end{array}$} & \multicolumn{1}{c}{ Kriteria } \\
\hline 1,0 & Sangat $\quad$ Kurang \\
$\leq \mathrm{H} / \mathrm{S}<1,8$ & Baik \\
1,8 & Kurang Baik \\
$\leq \mathrm{H} / \mathrm{S}<2,6$ & \\
2,6 & Cukup Baik
\end{tabular}

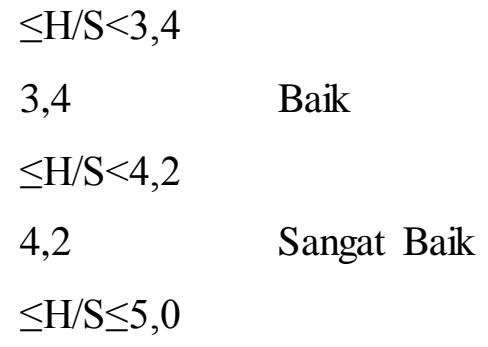

\section{HASIL DAN PEMBAHASAN}

Data hasil rerata pretest-postest hard skills dan soft skills yang dicapai mahasiswa dapat dideskripsikan secara statistik seperti tampak pada Tabel 3 .

Tabel 3. Descriptive statistics pretest-posttest hard skills dan soft skills mahasiswa

\begin{tabular}{cccccc}
\hline Skill & N & Min Max & Mean & $\begin{array}{c}\text { Std. } \\
\text { Deviation }\end{array}$ \\
\hline $\begin{array}{c}\text { Pretest } \\
\text { hard }\end{array}$ & 24 & 3.0 & 3.9 & 3.346 & .1911 \\
Pretest & & & & & \\
soft & 24 & 3.6 & 4.1 & 3.804 & .1628 \\
Posttest & & & & & \\
hard & 24 & 3.5 & 4.7 & 4.012 & .3207 \\
Posttest & & & & & \\
soft & 24 & 4.0 & 4.7 & 4.354 & .1693 \\
Valid N & 24 & & & & \\
\hline
\end{tabular}


Pada Tabel 3 nampak bahwa nilai pretest pada hard skills mempunyai nilai minimum 3,0 dan maksimal 3,9 sedangkan nilai mean yang diperoleh 3,3. Jika digunakan kriteria 2,6 $\leq$ Cukup Baik $<3,4 ; 3,4 \leq$ Baik < 4,2 maka kriteria hard skills mahasiswa Cukup Baik (54,17\%) dan Baik $(45,83 \%)$ dengan nilai rerata (mean) pretest hard skills berada dalam kategori Cukup Baik. Untuk soft skills memiliki nilai minimum 3,6 dan maksimal 4,1 dengan nilai mean 3,8. Jika digunakan kriteria $3,4 \leq$ Baik $<4,2$ maka kriteria soft skills mahasiswa Baik (100\%) dengan nilai rerata (mean) pretest soft skills berada dalam kategori Baik.

Pada saat pretest nilai hard skills dan soft skills mahasiswa masih dalam kategori sedang, hal ini disebabkan karena mahasiswa masih belum terbiasa menggunakan modul panduan praktikum berbasis guided inquiry. siswa pada awal pembelajaran tidak menikmati pembelajaran berbasis guided inquiry karena banyak kegiatan yang harus mereka lakukan sendiri walaupun bersamaan dengan hal tersebut, kecakapan siswa tumbuh dan mampu membangun pengetahuannya sendiri. (Trundle dkk, 2010; Zawadski, 2009; Minderhout \& Loertscher, 2007).

Berdasarkan Tabel 3 juga nampak bahwa nilai minimum posttest hard skills adalah 3,5 dan maksimal mencapai 4,7 dengan ratarata nilai sebesar 4,0. Jika digunakan kriteria $3,4 \leq$ Baik $<4,2 ; 4,2 \leq$ Sangat Baik $\leq 5,0 ;$ maka kriteria hard skills mahasiswa Baik $(66,67 \%)$ dan Sangat Baik $(33,33 \%)$ dengan nilai rerata (mean) pretest hard skills berada dalam kategori Baik. Sedangkan untuk nilai minimum posttest soft skill mahasiswa adalah 4,0 dengan maksimal sebesar 4,7 dan rata-rata nilai 4,4. Jika digunakan kriteria penilaian $3,4 \leq$ Baik < 4,2; 4,2 $\leq$ Sangat Baik $\leq 5,0 ;$ maka kriteria soft skills mahasiswa Baik $(4,17 \%)$ dan Sangat Baik $(95,83 \%)$ dengan nilai rerata (mean) pretest soft skills berada dalam kategori Sangat Baik.

Pada saat posttest nilai hard skills dan soft skill mahasiswa sudah mengalami peningkatan ke kategori baik dan sangat baik. Hal ini disebabkan mahasiswa sudah merasa tertarik untuk melakukan praktikum dengan menggunakan panduan 
praktikum fisika dasar 1 berbasis guided inquiry.

Hal ini sesuai dengan pendapat Massialas yang menyatakan bahwa Model inkuiri terbimbing adalah model mengajar yang memungkinkan siswa untuk bergerak selangkah demi selangkah dari mengidentifikasi masalah, mendefinisikan hipotesis, merumusan masalah, mengumpulan data, memverifikasi hasil, dan generalisasi kesimpulan. (Matthew dkk, 2013). Ada peningkatan yang lebih besar pada pemahaman sains dan keterampilan penyelidikan siswa ketika menggunakan panduan laboratorium berbasis inquiri. (Brickman dkk, 2009). Mereka juga menemukan bahwa siswa-siswa yang terlibat dalam pembelajaran berbasis inquiri memperoleh kepercayaan diri ketika mengembangkan kemampuan ilmiah.

Kemampuan inkuiri terbimbing dapat mempengaruhi perkembangan pengetahuan siswa. Membiasakan siswa belajar melalui proses kerja ilmiah, selain dapat melatih detail keterampilan ilmiah dan kerja sistematis, dapat pula membentuk pola berpikir siswa secara ilmiah.
(Rustaman, 2005). Sikap siswa dalam pembelajaran menggunakan perangkat pembelajaran IPA berorientasi inkuiri terbimbing termasuk dalam kategori sangat baik. Artinya siswa mampu bersikap secara ilmiah selama mengikuti pembelajaran dengan inkuiri terbimbing sehingga siswa secara tidak langsung telah mendapatkan pengalaman dalam pembelajaran. (Arsih dalam Syamsu, 2017).

Berdasarkan Tabel 3 maka dilakukan uji normalitas baik pada pretest-posttest hard skills maupun soft skills mahasiswa pada praktikum fisika dasar 1. Uji normalitas menggunakan One sample Kolmogorov Smirnov Test berbantuan software SPSS16 for windows. Hasil uji normalitas pretest-posttest hard skills dan soft skills mahasiswa tampak pada Tabel 4 dan Tabel 5.

Berdasarkan Tabel 4 diatas nampak bahwa nilai sig. Pretest hard skills adalah 0,189 sedangkan untuk soft skills memiliki signifikansi sebesar 0,202. Hal ini menunjukkan bahwa nilai signifikansi nilai pretest hard skills dan soft skills mahasiswa lebih besar dari $\alpha=0,05$. Karena 
nilai signifikansi lebih besar dari 0,05 maka sebaran data pretest hard skills dan soft skills mahasiswa terdistribusi normal.

Tabel 4. Hasil Uji Normalitas Pretest Hard Skills dan Soft Skills

\section{One-Sample Kolmogorov-Smirnov} Test

\begin{tabular}{llll}
\hline & & $\begin{array}{r}\text { hard } \\
\text { skills }\end{array}$ & $\begin{array}{c}\text { Soft } \\
\text { skills }\end{array}$ \\
\hline $\mathrm{N}$ & & 24 & 24 \\
Normal & Mean & 3.346 & 3.804 \\
Parameters & Std. & & \\
& Deviation & .1911 & .1628 \\
Most & Absolute & .222 & .219 \\
Extreme & Positive & .222 & .219 \\
Differences & Negative & -.197 & -.115 \\
Kolmogorov-Smirnov Z & 1.086 & 1.071 \\
\hline Asymp. Sig. & (2-tailed) & .189 & .202 \\
\hline
\end{tabular}

Pada Tabel 5 nampak bahwa nilai sig. Posttest hard skills adalah 0,403 sedangkan untuk soft skills memiliki signifikansi sebesar 0,514. Hal ini menunjukkan bahwa nilai signifikansi nilai posttest hard skills dan soft skills mahasiswa lebih besar dari $\alpha=0,05$. Karena nilai signifikansi lebih besar dari 0,05 maka sebaran data posttest hard skills dan soft skills mahasiswa terdistribusi normal.

Tabel 5. Hasil Uji Normalitas Posttest Hard Skills dan Soft Skills

One-Sample Kolmogorov-Smirnov Test

\begin{tabular}{llcc}
\hline & & $\begin{array}{c}\text { Hard } \\
\text { skills }\end{array}$ & $\begin{array}{c}\text { Soft } \\
\text { skills }\end{array}$ \\
\hline $\mathrm{N}$ & & 24 & 24 \\
Normal & Mean & 4.012 & 4.354 \\
Parameters $^{\mathrm{a}}$ & Std. & & \\
& Deviation & .3207 & .1693 \\
& Absolute & .182 & .167 \\
Most & Positive & .182 & .167 \\
Differences & Negative & -.087 & -.140 \\
Kolmogorov-Smirnov $\mathrm{Z}$ & .893 & .819 \\
Asymp. Sig. & (2-tailed) & .403 & .514 \\
\hline
\end{tabular}

Sebaran data pretest-posttest hard skills dan soft skills mahasiswa berdistribusi normal sehingga selanjutnya dilakukan uji parametrik, yaitu dengan uji paired-samples $t$ test dengan bantuan aplikasi SPSS 16 for windows. Uji paired-samples $\mathrm{t}$ test berfungsi untuk mengetahui ada tidaknya perbedaan hard skills dan 
Tabel 6. Hasil Uji $\mathbf{t}$ hard skills dan soft skills mahasiswa

Paired Samples Test

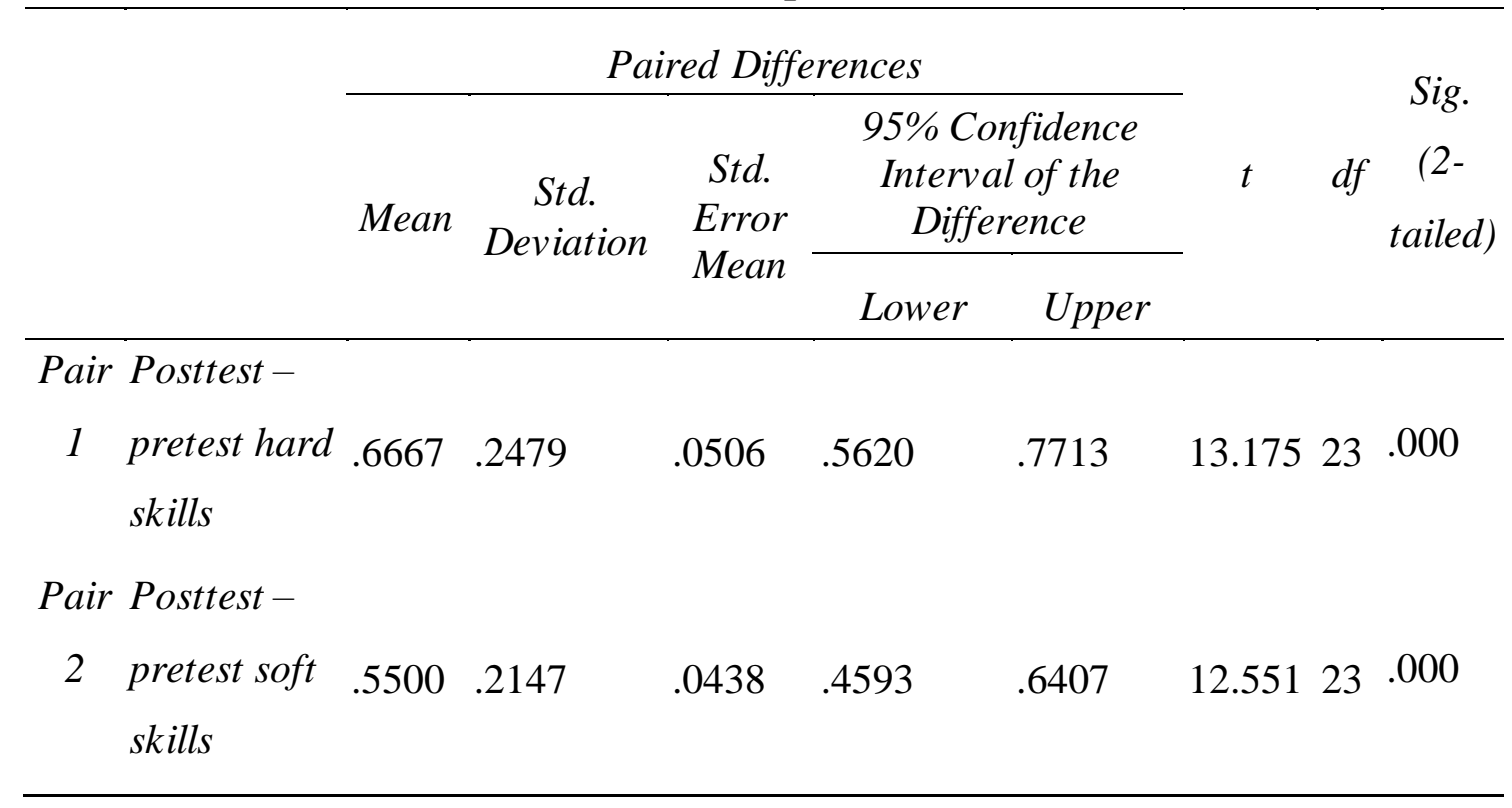

soft skills yang diperoleh mahasiswa setelah mengikuti praktikum menggunakan modul panduan.

Praktikum fisika dasar I berbasis inkuiri terbimbing. Uji paired-samples $\mathrm{t}$ test dipilih karena uji ini cocok digunakan untuk mengukur ada tidaknya perbedaan yang signifikan antara dua variabel dari suatu group sampel tunggal yang berdistribusi normal. Hasil uji dari nilai pretest dan posttest hard skills maupun soft skills nampak pada Tabel 6. Berdasarkan Tabel 6 nampak bahwa nilai t test hard skills adalah 13,175 pada taraf signifikansi $\alpha=0,05$ dan derajat kebebasan $(\mathrm{df}=$ 23). Nilai signifikansi hard skills mahasiswa yang diperoleh setelah dan sebelum perlakuan adalah 0,00 lebih besar dari $\alpha=0,05$. Hal ini dapat diinterpretasikan bahwa $\mathrm{H}_{0}$ ditolak yang berarti ada perbedaan yang signifikan hard skills mahasiswa setelah dan sebelum perlakuan.

Hal yang sama juga didapatkan dari hasil penelitian (Feriyadi dkk, 2015) yang menyimpulkan bahwa penggunaan LKS berbasis Inkuiri Terbimbing dapat meningkatkan Keterampilan Proses Sains (hard skills) siswa pada materi pokok pencemaran dan dampaknya bagi makhluk hidup. Hal ini sesuai dengan hasil penelitian (Waliyah 
dkk, 2016) menyimpulkan bahwa ada perbedaan yang signifikan kemampuan kerja ilmiah mahasiswa sebelum dan sesudah menggunakan petunjuk kimia dasar 1 berbasis inkuiri terbimbing.

Dari Tabel 6 diatas juga nampak bahwa soft skills memiliki nilai t-test sebesar 12,551 pada taraf signifikansi $\alpha=0,05$ dan derajat kebebasan $(\mathrm{df}=23)$. Sedangkan untuk nilai signifikansi soft skills mahasiswa setelah dan sebelum perlakuan adalah 0,00 lebih besar dari $\alpha=0,05$. Hal ini dapat diinterpretasikan bahwa $\mathrm{H}_{0}$ ditolak yang berarti ada perbedaan yang signifikan soft skills mahasiswa setelah dan sebelum perlakuan.

Guided inquiry dapat melatih peserta didik membangun jawaban dan berpikir cerdas dalam menemukan berbagai alternatif solusi atas permasalahan yang diajukan oleh pendidik, mengembangkan keterampilan pemahaman konsep, membangun rasa tanggung jawab dan melatih proses penyampaian konsep yang ditemukan. (Bilgin, 2009). Hal ini sesuai dengan apa yang dikemukakan oleh Gulo bahwa proses model pembelajaran inkuiri tidak hanya mengembangkan kemampuan intelektual tetapi seluruh potensi yang ada termasuk pengembangan emosional dan keterampilan. (Trianto, 2007).

Berdasarkan hasil uji hipotesis diatas maka dapat disimpulkan bahwa ada pengaruh yang signifikan penggunaan panduan praktikum fisika dasar 1 terhadap peningkatan hard skills dan soft skill mahasiswa (calon guru fisika).

Hasil yang sama dikemukakan oleh (Ariesta dkk, 2011) dalam penelitiannya yang menunjukkan perolehan persentase kerja ilmiah mahasiswa secara klasikal sebesar 91,67\% dengan kriteria sangat baik, sikap ilmiah dengan persentase $87,50 \%$ dengan kriteria sangat baik, penyusunan laporan oleh mahasiswa dengan persentase $76,88 \%$ dengan kriteria baik, serta peningkatan ratarata hasil belajar \{rata-rata gain pertemuan pertama 0,58 (sedang), pertemuan kedua 0,56 (sedang), pertemuan ketiga 0,7 (sedang), dan pertemuan keempat 0,93 (tinggi)\}. Hal ini menunjukkan bahwa hard skill (kerja ilmiah, penyusunan laporan, hasil belajar) dan soft skill (Sikap Ilmiah) mengalami 
peningkatan setelah menggunakan perangkat pembelajaran berbasis guided inquiry.

Pendapat yang sama juga ditunjukkan dalam penelitian yang dilakukan oleh Nurussaniah yang menyimpulkan bahwa adanya peningkatan kemampuan berpikir kritis mahasiswa setelah menggunakan Penuntun Praktikum Fisika Dasar 1 berbasis Guided Inquiry dikategorikan sedang dengan nilai gain 0,64. (Nurussaniah dkk, 2016). Pembelajaran IPA sebaiknya dilaksanakan secara inkuiri ilmiah untuk menumbuhkan kemampuan berfikir, bekerja dan bersikap ilmiah serta mengkomunikasikannya sebagai aspek penting kecakapan hidup. (Sulistyorini, 2007). Berdasarkan uraian di atas maka dapat diketahui bahwa ada pengaruh yang positif penggunaan panduan praktikum fisika dasar 1 berbasis guided inquiry terhadap peningkatan hard skills dan soft skills mahasiswa (calon guru fisika) pada matakuliah praktikum fisika dasar 1.

\section{SIMPULAN}

Berdasarkan hasil penelitian dan pembahasan maka dapat disimpulkan bahwa:

Ada pengaruh yang signifikan penggunaan panduan praktikum fisika dasar 1 berbasis guided inquiry terhadap peningkatan hard skill dan soft skills mahasiswa.

Saran yang dapat diberikan berdasarkan hasil penelitian adalah:

Penggunaan panduan praktikum fisika dasar 1 berbasis guided inquiry harus direncanakan sebaik mungkin dengan RPP yang berbasis guided inquiry juga sehingga pengelolaan waktu dapat dikelola dengan baik. Selain itu kondisi mahasiswa selama praktikum berlangsung juga perlu diperhatikan sehingga praktikum dapat terlaksana dengan baik dan lancar.

Praktikum dengan menggunakan panduan berbasis guided inquiry membutuhkan pengaturan waktu dan persiapan yang baik, karena memiliki tahapan yang banyak sehingga memerlukan waktu yang banyak pula. Perlu adanya pelatihan co-asisten lab sehingga praktikum berjalan sesuai dengan yang diharapkan. 
Perlu adanya penelitian yang sejenis untuk matakuliah praktikum yang lain sehingga kemampuan hard skills dan soft skills mahasiswa semakin tinggi serta para pendidik (dosen) dan calon pendidik (mahasiswa) lebih terampil menggunakan model pembelajaran guided inquiry.

\section{UCAPAN TERIMA KASIH}

Ucapan terimakasih saya sampaikan kepada: 1) DRPM sebagai sumber dana dalam penelitian ini; 2) Kepada Laboran Lab. Terpadu yang sudah mengijinkan kami menggunakan Laboratorium Terpadu untuk melakukan praktikum fisika dasar 1 berbasis guided inquiry.

\section{DAFTAR RUJUKAN}

Aji, S. D., \& Hudha, M. N. 2015. Dampak PBL Terhadap Kerja Ilmiah Mahasiswa pada Perkuliahan Pengembangan Media Pembelajaran. Jurnal Inspirasi Pendidikan, 6(1), 708714.

Bilgin, I. 2009. The Effects of Guided Inquiry Instruction Incorporating with Cooperative Learning Environment on
University Students'

Achievement of Acid and Bases Concepts and Attitude Toward Guided Inquiry Instruction. Scientific Research and Essay Vol.4 (10), pp. 1038-1046.

Brickman, P., Hallar, B., Gormally, C., \& Armstrong, N. 2009. Effect of Inquiry-based learning on Students' science literacy skill and confidence. International journal for the scholarship of teaching and learning (ijstol) Vol. 3, No. 2 hal 1-22. Georgia Southern University.

Feriyadi, E., Achmad, A.,Marpaung, T. Rini. R. 2015. Pengaruh Lembar Kerja Siswa Berbasis Inkuiri Terbimbing Terhadap Keterampilan Proses Sains. Bioterdidik Vol 3 no 9 hal 102110.

Fitra, D., Elfayetti., S. Tumiar. 2016. Peningkatan soft skills dan hard skills mahasiswa melalui Project-based learning pada mata kuliah Perencanaan pembelajaran geografi. Jurnal geografi Vol 8 No 2 hal.124135. 
Abrahams, I. 2011. Practical Work in Secondary Science: A MindsOn Approach. Continuum International Publishing Group, India: Replika Press Pvt Ltd.

Matthew, M. B., Kenneth, I. O. 2013. A Study On The Effects Of Guided Inquiry Teaching Method On Students Achievement In Logic. The International Research Journal, International Researcher Volume No.2 Issue No. 1 March hal 133-140.

Minderhout \& Loertscher. 2007. Lecture-free biochemistry a process oriented guided inquiry approach. Biochemistry And Molecular Biology Education. Vol. 35, No. 3, pp. 172-180.

Nurussaniah., N. 2016.

Pengembangan Penuntun

Praktikum Fisika Dasar 1

Berbasis Guided Inquiry Untuk Meningkatkan Kemampuan

Berpikir Kritis Mahasiswa. Seminar Nasional Fisika (SNF) hal 63-68. Prodi Pendidikan Fisika dan Fisika, Fakultas MIPA, Universitas Negeri Jakarta
Ariesta, R., \& Supartono. 2011. Pengembangan Perangkat Perkuliahan Kegiatan Laboratorium Fisika Dasar II Berbasis Inkuiri Terbimbing untuk Meningkatkan Kerja Ilmiah Mahasiswa. Jurnal Pendidikan Fisika Indonesia. Vol (7) No 1: 62-68.

Rustaman, N.Y. 2005. Strategi Belajar Mengajar IPA. Malang: UM Press.

Sailah, I. 2008. Pengembangan Soft Skills di Perguruan Tinggi. Tim Kerja Pengembangan Soft Skills.

Direktorat Jenderal Pendidikan Tinggi

Schreiber, J. B. 2011. Educational Research: Interelationship of Questions, Sampling, Design, and Analysis. USA: John Wiley\&Sons,INC.

Sulistyorini, S. 2007. Pembelajaran IPA Sekolah Dasar. Semarang: Tiara Wacana

Syamsu, D. F. 2017. Pengembangan Penuntun Praktikum IPA Berbasis Inkuiri Terbimbing Untuk Siswa SMP Siswa Kelas VII Semester Genap. 
BIOnatural Volume 4 No. 2,

Page : 13-27.

Trianto. 2007. Model-model Pembelajaran Inovatif Berorientasi Konstruktivistik. Surabaya: Prestasi Pustaka.

Trundle, K. C., Atwood, R. K., Christopher, J. E., \& Sackes, M. 2010. The Effect of Guided Inquiry-Based Instruction on Middle School Students' Understanding of Lunar Concepts. Res Sci Educ. 40:451-478.

Waliyah, I., Harun, I.A., Rasmawan, R. 2016. Pengaruh Petunjuk 